\title{
Soil Stabilization by using Scrap Tire Rubber
}

\author{
Ms. Deepti V. Zutting \\ PG student, Civil Engineering, \\ School of Engineering and Technology, \\ Sandip University, Nashik.
}

\author{
Prof. (Dr.) P. L. Naktode \\ Guide \& Head of department, Civil Engineering, \\ School of Engineering and Technology, \\ Sandip University, Nashik.
}

\begin{abstract}
The amount of tire wastes, an unwanted urban-industry surplus, has been increasing every year throughout the world. One of the chances to dispose of this waste material is to use these refuses, as a stabilizer in soils, in order to increase the strength properties and the bearing capacity of the soil-stabilizer mixture. In this thesis, in order to study the influence of crumb rubber waste on relative density and shear strength, series of experiments have been performed on dune sand samples with different dune sandcrumb rubber ratios. Various dune sand-crumb rubber mixtures having $0 \%, 5 \%, 10 \%, 15 \%, 20 \%, 25 \%$ and $30 \%$, waste crumb rubber particles by weight were chosen. To find the effect of waste crumb rubber on shear strength, direct shear test device has been used. It was found that addition of up to $20 \%$ of crumb rubber to dune sand noticeably increased the shear strength parameters: cohesion and the internal friction angle. The dune sand-crumb rubber mixture created more plastic material and produced an apparent cohesion in the crumb rubber treated dune sand. Since dune sand- crumb rubber mixtures are lightweight materials and they apply less lateral earth pressures on retaining structures, application of crumb rubber into the dune sand is still promising.
\end{abstract}

\section{Key Words : Soil Stabilization, Scrap Tire Rubber, Crumb Rubber}

\section{INTRODUCTION}

Soil is the smallest natural element which exists on the earth's crust and it is one the oldest natural mortars that has been used in the construction industries during time (Das, 2009). The world's architecture and the ruins of its work are indebted to this element and its attributes. Despite all the new materials we have now a day, large amount of soil is still being used directly or indirectly in the construction industries. As of the creation view, soil is the final production of weathering, result of physical destruction and chemical degradation of stones along with aggregation of leftovers of the organisms in decay by nature (biodegrades) (Das, 2009). All along the history, mankind has been trying to find a better use of soil in different matters. We can find the origin of this idea in natural models and examples. Lots of species specially birds, they mix soil and tiny branches to build their nests or the hillsides will be stabilized by the plant growth and their roots. The idea of mixing straw and clay to build thatch mortar or recently the use of shredded tires and polymer fibers to reinforce the materials and soil structures are the samples of this idea (Das, 2009). Soil reinforcement is one of the geotechnical branches which has been reinforcing and improving the soil engineering specifications and mechanical properties like strength, plasticity, bearing capacity and elasticity modules by the use of new technologies and 2 suitable materials (Craig, 2004). Soil reinforcement is a reliable and effective method to improve the soil strength and stabilization which has always been the human interest. Around 3000 years ago Babylonian used reinforced soil with thatch to build their temples (Mwasha, 2009). At the present times, the elements which are used in soil reinforcement are made of metal or polymeric materials or even herbal like jute and Coir fiber geotextiles (GalánMarín et al. 2012). Friction phenomena between the soil and its reinforcement materials play an important role in mechanism of action and behavior in soil. One the methods of soil reinforcement is, integration of soil with fibers like natural, glass, polymer or other synthetic materials. Mixture of these elements with soil creates a complex environment in which the involvement of the elastic parts (reinforcement elements) and soil particles improves the soil strength and plasticity in many ways like increase in peak strength, reduction in post-peak loss of strength and axial strain at failure (Haeri et al., 2000). There have been many elements like metal fibers or fiber glass or polymeric fibers and etc., which have been applied to soils as soil reinforcement (Haeri et. al., 2000) and (Jewell \& Greenwood, 1988) studied the mechanical effects of geotextile reinforcement (Prabakar\& Sridhar, 2000) investigated addition of sisal fiber (Yeung et. al., 2007) studied the glass-fiber reinforcement. We can categorize the methods of soil reinforcements into three categories of mechanical, physical and chemical processes

\section{LITERATURE REVIEW}

Being the most available material, soil has always been used in construction of different structure like buildings, roads and dams. Due to weak mechanical properties, the structures made of soil are much bulkier, heavier and dimensionally larger. Because of these weaknesses, there are many researches aimed at enhancing the mechanical properties of soil and increasing its strength via adding different materials. Reinforced earth is one type of enhanced soil that its tensile strength is increased. Although the addition of tensile resistant fibers to soil have been practiced by ancient civilizations but, the new technologies and advances in this field made the use of soil economically and technically much more justified and feasible. There are many method and technologies in used to increase the tensile strength of the soil through mixing various additive or fibers to soil. Since the introduction of these methods, comprehensive theoretical and practical researches have been under way and some codes and standards developed for these methods. The reinforcement of the soil is not new concept and its first applications goes back to 4 to 5 thousand years B.S when, hey or straw were used to reinforce the clay or bricks. There are other evidences indicating use of reinforced soil in china wall and also ancient African and South Asian people used bamboo sheets, straw and date leaf in their buildings. One of the materials used for enhancing the properties of soil is tire derived products like tire shreds, 
crumbs or powder. For this study a comprehensive literature review has been carried out that is summarized in this chapter. It covers the material properties of recycled tire, related tests and geotechnical applications of this material

\begin{tabular}{|c|c|c|c|c|}
\hline \multirow[t]{2}{*}{ Authors } & \multicolumn{2}{|c|}{ Materials used } & \multirow[t]{2}{*}{ Test conducted } & \multirow{2}{*}{ Conclusions } \\
\hline & Type of soil & $\begin{array}{l}\text { Type of waste rubber } \\
\text { tyre }\end{array}$ & & \\
\hline $\begin{array}{l}\text { Ahemd et al. } \\
\text { (1993) }\end{array}$ & $\begin{array}{l}\text { 1. Poorly graded sand } \\
\text { 2. Sand-silty clay }\end{array}$ & 1. Tyre chips & Tri-axial test & $\begin{array}{l}\text { The stress strain behavior of poorly } \\
\text { graded sand is changed due to mixing } \\
\text { of tyre chips for different } \\
\text { percentages. }\end{array}$ \\
\hline Foose et al. (1996) & 1.Dry sand & 1.Shred tyre & Direct shear tests & $\begin{array}{l}\text { Normal stress, shred content, and sand } \\
\text { matrix unit weight affecting shear } \\
\text { strength }\end{array}$ \\
\hline Y. Wu et al. (1997) & 1.Dry sand & 1.Tyre chip & $\begin{array}{l}\text { Tri-axial } \\
\text { compression tests }\end{array}$ & $\begin{array}{l}\text { Strength parameter } \\
\text { obtained with constant } \sigma 1 \text { was more } \\
\text { reasonable }\end{array}$ \\
\hline Bernal et al. (1997) & 1.Dry sand & $\begin{array}{l}\text { 1.Tyre shred 2.Rubber } \\
\text { sand }\end{array}$ & $\begin{array}{l}\text { Direct shear tests, } \\
\text { interface direct shear } \\
\text { tests, and geo- synthetic } \\
\text { pullout tests }\end{array}$ & $\begin{array}{l}\text { Constructing geo- synthetic- reinforced } \\
\text { fills containing tyre shreds include ease } \\
\text { of construction (because material } \\
\text { handling is similar to that of } \\
\text { conventional materials), reduction of } \\
\text { earth pressures, limited deformation of } \\
\text { the facing, and a reduction in the } \\
\text { contact pressure with the } \\
\text { underlying soils }\end{array}$ \\
\hline $\begin{array}{l}\text { Tweedie et al. } \\
\text { (1998) }\end{array}$ & 1.Sand & 1.Tyre shreds & 1.Tri-axial test & $\begin{array}{l}\text { The inclination of the sliding plane } \\
\text { with respect to horizontal was } \\
\text { estimated to range from }\end{array}$ \\
\hline
\end{tabular}

MATERIAL

The main concern of the tire based industries is to dispose of waste tires safely and economically. Main cause of this problem is there are huge quantities of discarded tires in all over the world. Hence large scale utilization of discarded tires in geotechnical constructions will reduce the problems faced by the waste tire industries. In this connection assessment of the behavior of structures constructed using waste tires as chips, shredded or in powder form is required for stability and safe functioning of structures. Even through adequate substitute for full scale field tests are not available; tests at laboratory scale have the advantage of allowing a close control of many of the variable encountered in practice. The behavior pattern trends and measured in the laboratory tests can be used in understanding the performance of the structures in the field and may be used in formulating mathematical relationship to predict the behavior of field structures. In the present work the behavior of dune sand randomly reinforced with waste tires has been evaluated through a series direct shear test. Details of material used, sample preparation and testing procedure adopted have been outlined in this chapter. 


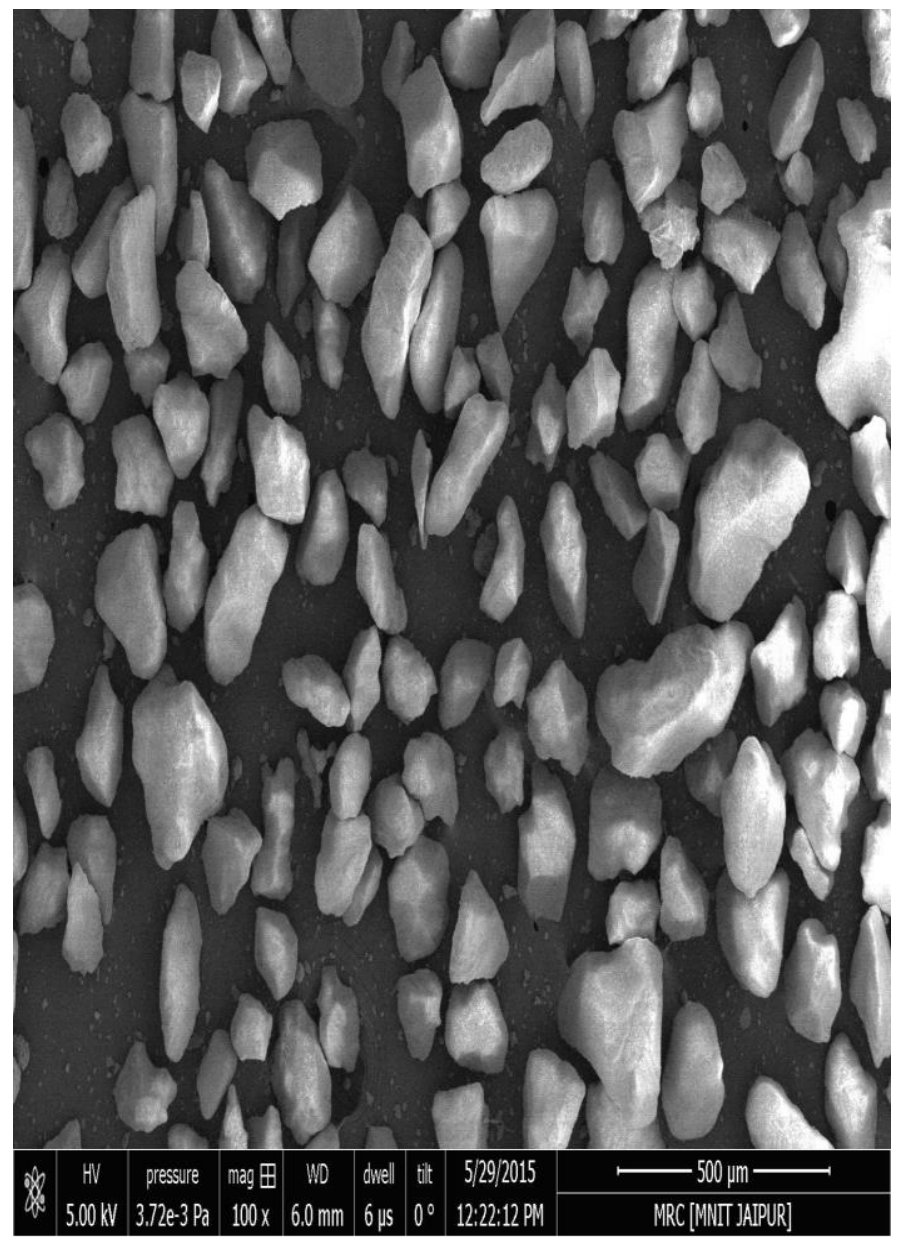

\begin{tabular}{|c|c|}
\hline Physical parameter & Values \\
\hline Specific gravity & 2.667 \\
\hline Liquid limit (\%) & - \\
\hline Plastic limit (\%) & - \\
\hline Plasticity index & 0 \\
\hline Minimum dry density & $1.318 \mathrm{~g} / \mathrm{cm}^{3}$ \\
\hline Maximum dry density & $1.652 \mathrm{~g} / \mathrm{cm}^{3}$ \\
\hline Effective particle size( D10) & 0.825 \\
\hline Coefficient of uniformity $(\mathrm{Cu})$ & 1.818 \\
\hline Coefficient of curvature $(\mathrm{Cc})$ & 0.808 \\
\hline OMC\% & 14.90 \\
\hline Coefficient of permeability $(\mathrm{cm} / \mathrm{sec})$ & $5.650 \times 10^{-4}$ \\
\hline $\begin{array}{l}\text { Classification based on plasticity characteristics } \\
\text { (AS PER IS) }\end{array}$ & SP \\
\hline
\end{tabular}

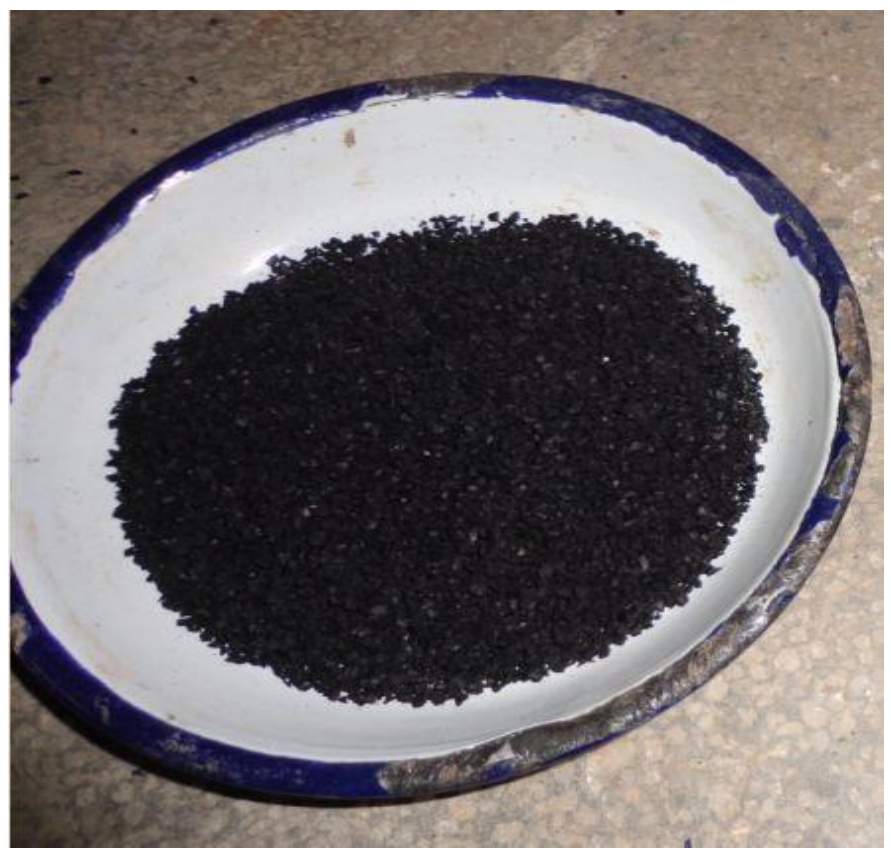

\begin{tabular}{|l|l|}
\hline Properties & Value \\
\hline Specific gravity & 1.12 \\
\hline Water absorption & $2 \%$ \\
\hline Cut length(mm) & 25,50 \\
\hline Aspect ratio & $1: 2$ \\
\hline
\end{tabular}




\section{METHODOLOGY}

Three phases were conducted to perform overall testing program. In first phase we study the geotechnical characteristics of the dune sand and physical properties of shredded tires, which were already being discussed. In the second phase to calculate the different percentage of waste tires, we calculates the maximum dry unit weight and minimum dry unit weight for the mix by the use of relative density table apparatus. To determine the relative density of cohesionless the relative density test was performed, by the use of free-draining soils on a vibrating table. The relative density of a soil is the ratio, expressed as a percentage, of the difference between the maximum void ratio and the field void ratio of a cohesionless, free-draining soil; to the difference between its maximum and minimum void ratios.
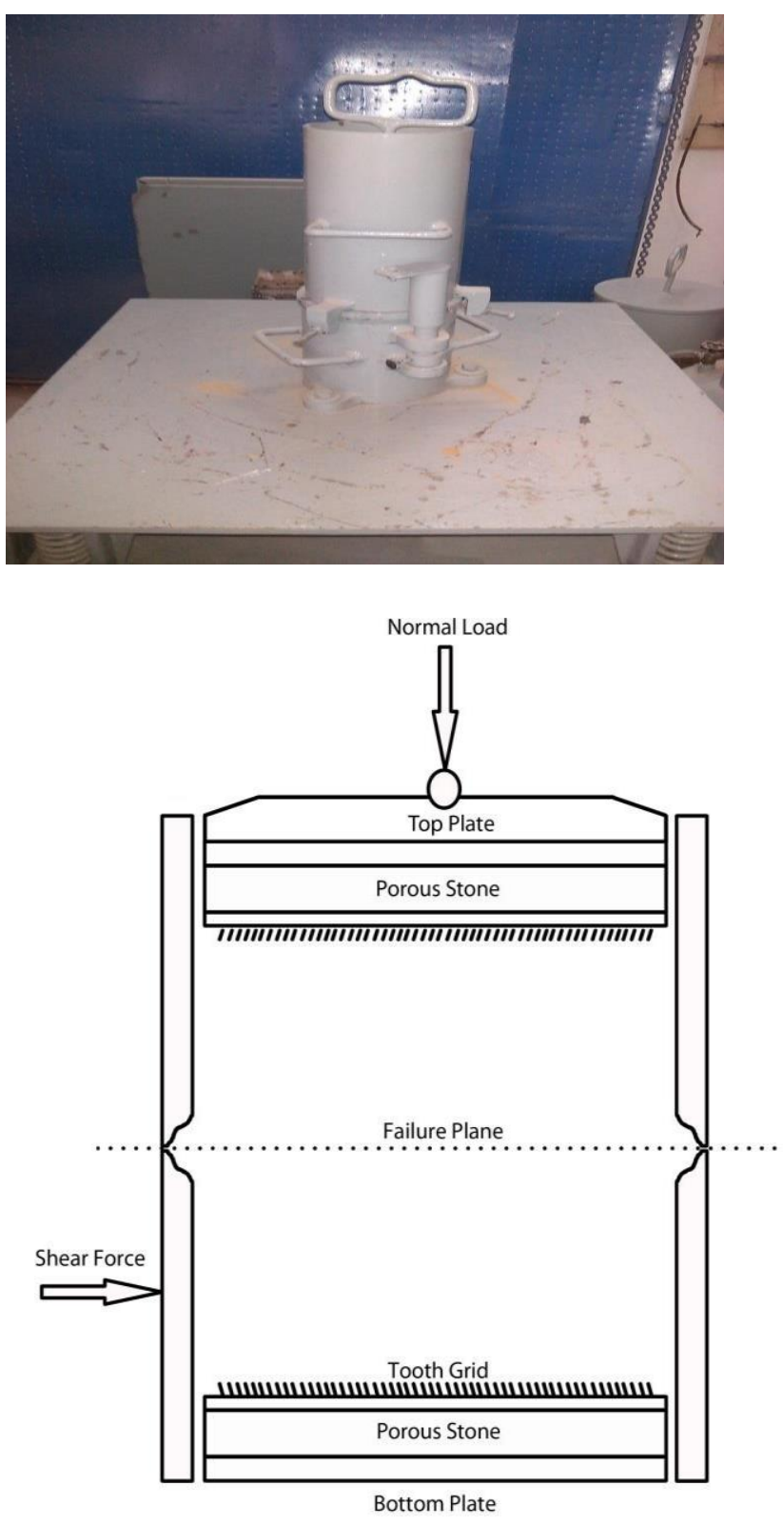

\begin{tabular}{|c|c|}
\hline Dune sand (\%) & Waste crumb rubber (\%) \\
\hline 100 & 0 \\
\hline 95 & 5 \\
\hline 90 & 10 \\
\hline 85 & 15 \\
\hline 80 & 20 \\
\hline 75 & 25 \\
\hline 70 & 30 \\
\hline
\end{tabular}

\begin{tabular}{|c|c|c|}
\hline$\%$ Tire & $\begin{array}{c}\text { Mass of Dune Sand } \\
(\mathrm{gm})\end{array}$ & $\begin{array}{c}\text { Mass of Crumb } \\
\text { rubber }\end{array}$ \\
\hline 0 & 165.81 & 0 \\
\hline 5 & 157.51 & 8.29 \\
\hline 10 & 149.22 & 16.58 \\
\hline 15 & 140.93 & 24.87 \\
\hline 20 & 132.64 & 33.16 \\
\hline 25 & 124.35 & 41.45 \\
\hline 30 & 116.06 & 49.74 \\
\hline
\end{tabular}


The purpose of observing the behavior of dune sand,crumb rubber, and their mixtures, Standard Direct Shear Test Device $(60 \mathrm{~mm} \times 60 \mathrm{~mm})$ was utilized. The thickness of the samples was $50 \mathrm{~mm}$. All tests were done based on the method explained in ASTM D3080-72 (1989). In all tests, three normal stresses of 50, 100, and 200kPa were applied. Samples included pure dune sand, crumb rubber, and their mixture based on different percentages of weight of $0 \%, 5 \%, 10 \%, 15 \%, 20 \%, 25 \%$ and $30 \%$ crumb rubber mixed with dune sand. Numerical calculations of each sample were done based on the maximum and minimum of dry density and the relative density of $70 \%$, as a dense mixture, was considered to determine the weight of the sample to be compacted in the Shear Box Device. When the samples got ready, placed in the shear box, and by reached the relative density (by compacting) the normal stresses were applied and samples were sheared. All the tests were done based on controlleddisplacement. Shear rate in Standard Direct Shear Test is usually controlled by an electric motor and a multi-speed drive unit, typically providing 24 speeds ranging from $5 \mathrm{~mm} / \mathrm{min}$ to about $0.0003 \mathrm{~mm} / \mathrm{min}$ (Head, 1982).In all experiments that were done in this study, shear rate was considered $1 \mathrm{~mm} / \mathrm{min}$ which was close to the rates considered by other researchers.

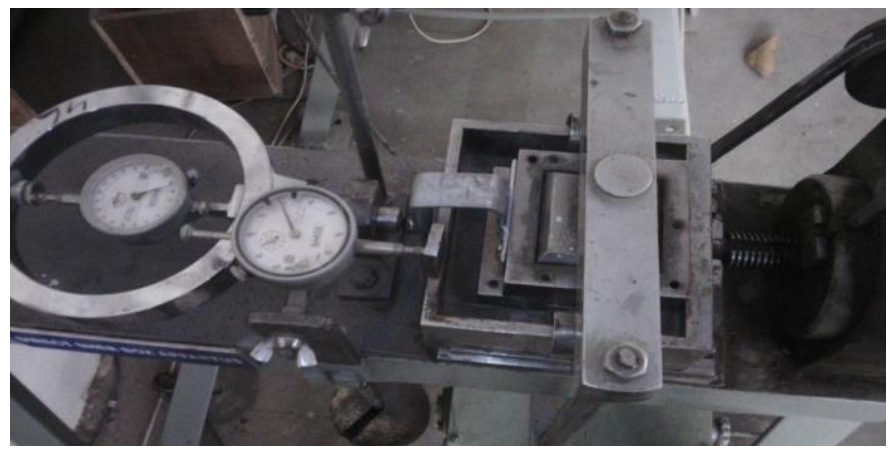

The waste crumb rubberare used is this study was taken from the waste tires industries in different form i.e. powder, chips and shredded form. The size of crumb rubber used in the study are ranged from $0.8-2 \mathrm{~mm}$. Fig illustrate the grain size distribution curve of crumb rubber. The engineering properties of crumb rubber

\begin{tabular}{|c|c|c|c|}
\hline \% Crumb rubber & $\begin{array}{c}\text { Maximum Dry Density } \\
(\gamma \mathrm{dmax})(\mathbf{d e n s e} \mathbf{s t a t e})\left(\mathbf{K N} / \mathbf{m}^{\mathbf{3}}\right)\end{array}$ & $\begin{array}{c}\text { Minimum Dry Density } \\
(\gamma \mathrm{dmin})\left((\mathbf{l o o s e} \mathbf{s t a t e})\left(\mathbf{K N} / \mathbf{m}^{\mathbf{3}}\right)\right.\end{array}$ & Dry Density $(\gamma \mathbf{d})\left(\mathbf{K N} / \mathbf{m}^{\mathbf{3}}\right)$ \\
\hline 0 & 16.5 & 13.2 & 14.2 \\
\hline 5 & 15.5 & 12.6 & 13.8 \\
\hline 10 & 14.3 & 12.0 & 13.5 \\
\hline 15 & 14.2 & 11.9 & 13.4 \\
\hline
\end{tabular}

\begin{tabular}{|c|c|c|c|c|c|c|c|}
\hline \multirow{3}{*}{$\begin{array}{c}\text { Shear } \\
\text { Displacement (mm) }\end{array}$} & \multicolumn{7}{|c|}{ Shear Stress (KPa) } \\
\hline & $0 \%$ & $5 \%$ & $10 \%$ & $15 \%$ & $20 \%$ & $25 \%$ & $30 \%$ \\
\hline & $\begin{array}{l}\text { Crumb } \\
\text { rubber }\end{array}$ & $\begin{array}{l}\text { Crumb } \\
\text { rubber }\end{array}$ & Crumb rubber & Crumb rubber & $\begin{array}{l}\text { Crumb } \\
\text { rubber }\end{array}$ & $\begin{array}{l}\text { Crumb } \\
\text { rubber }\end{array}$ & Crumb rubber \\
\hline 0 & 0 & 0 & 0 & 0 & 0 & 0 & 0 \\
\hline \multirow[t]{2}{*}{2} & 13.5 & 13.6 & 13.75 & 13.85 & 14 & 13.5 & 13 \\
\hline & 12 & 13.5 & 15 & 15.5 & 16 & 14 & 12.75 \\
\hline 6 & 10 & 12.0 & 13.5 & 14.5 & 15.5 & 14 & 12.5 \\
\hline 8 & 10 & 11.5 & 13 & 14 & 15 & 13.5 & 12.5 \\
\hline 10 & 10 & 11.5 & 13 & 14 & 15 & 13.5 & 12.5 \\
\hline
\end{tabular}

\section{RESULTS AND DISCUSSION}

The aim of these tests is to investigate the effects crumb rubber on strength parameters of dune sand. The use of randomly reinforced crumb rubber with dune sand requires a proper understanding of the interaction between the crumb rubber and dune sand. Hence the series of some randomly laboratory test such as direct shear box tests, relative density test should be carried out on dune sand with different proportions of crumb rubber. The relative density of dune sand is taken $70 \%$ as a dense mixture and calculated the maximum dry density and minimum dry density of each mixture by the use of relative density test.For calculating the weight of the samples which was to be filled in the direct shear box apparatus calculate dry density of each mix using maximum and minimum dry density. 

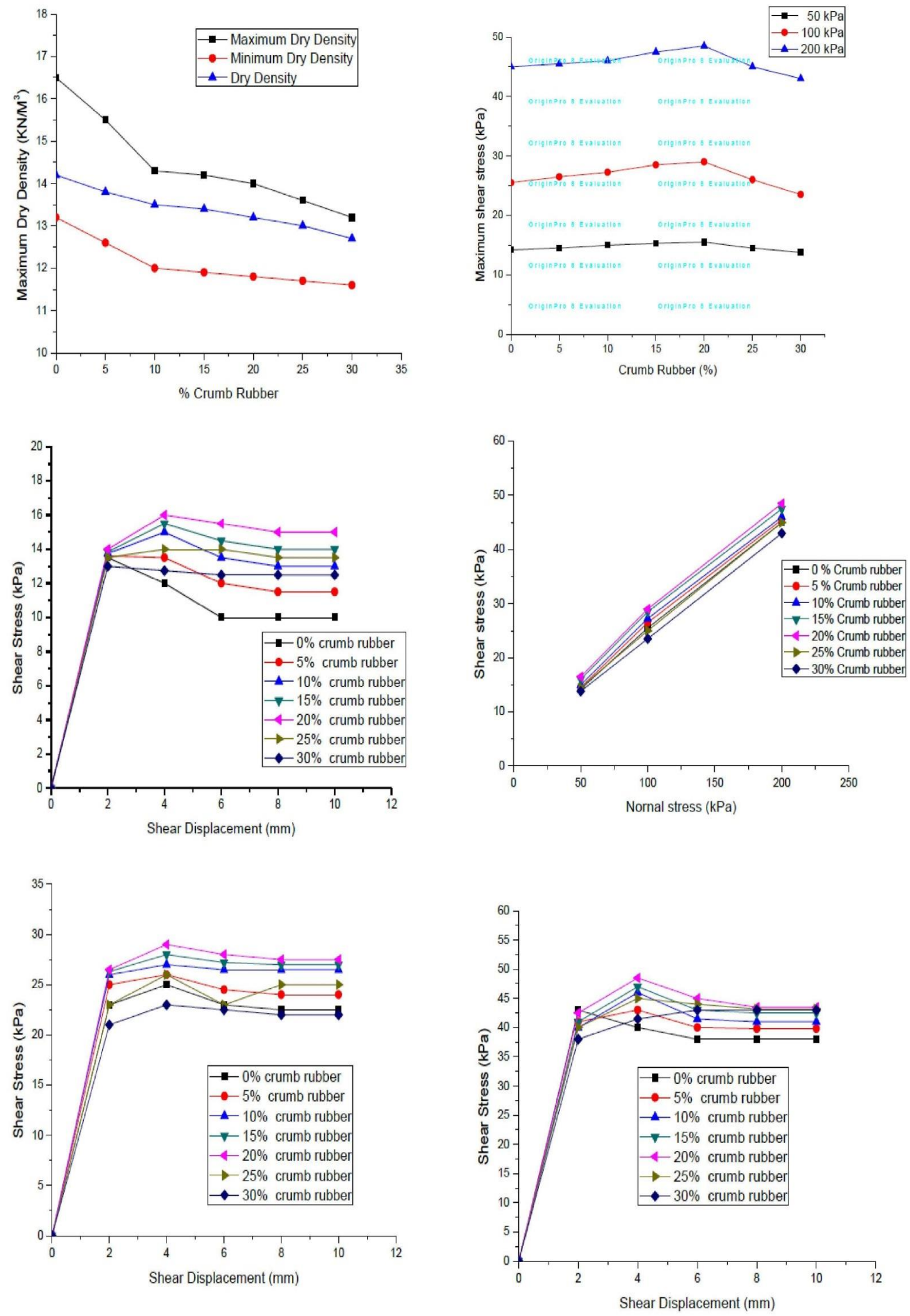


\section{CONCLUSION}

The application of recycled tire waste has a positive effect on the engineering properties of the poorly graded dune sand. Crumb rubber consists the potential to improve the strength of treated dune sand. Based on the test results of direct shear test the following conclusions can be drawn:-

1. The shear strength of the crumb rubber and dune sand mixture is greater than the dune sand alone.

2. Crumb rubber increases the value of internal friction angle from 31.30 to 32.750 for $0 \%$ crumb rubber to $20 \%$ crumb rubber.

3.Form $30 \%$ crumb rubber, the value of internal friction angle decreases subsequently to $100 \%$ crumb rubber.

4.The dry density of dune sand is $14.2 \mathrm{KN} / \mathrm{m} 3$ and it decreases upto $11.78 \mathrm{KN} / \mathrm{m} 3$ for $30 \%$ crumb rubber and for optimum $20 \%$ it is $13.2 \mathrm{KN} / \mathrm{m} 3$, indicates that it can be used in lightweight backfill material which leads to decrease in lateral pressure.

5.Thus, the shear strength of dune sand is maximum for $20 \%$ crumb rubber and decreases for more tire percentage.

6. Moreover, by adding crumb rubber, the weight of the mixture decreases which also leads to decreases in the lateral earth pressure.

\section{REFERENCE}

[1] Tatlisoz, Nilay, Craig H. Benson, and Tuncer B. Edil. "Effect of fines on mechanical properties of soil-tire chip mixtures." ASTM SPECIAL TECHNICAL PUBLICATION 1275 (1997): 93-124.

[2] Eldin, Neil N., and Ahmed B. Senouci. "Use of scrap tires in road construction." Journal of Construction Engineering and Management 118, no. 3 (1992): 561-576.

[3] Zornberg, Jorge G., Alexandre R. Cabral, and ChardphoomViratjandr. "Behaviour of tire shred sand mixtures." Canadian Geotechnical Journal 41, no. 2 (2004): 227-241.

[4] Youwai, Sompote, and Dennes T. Bergado. "Strength and deformation characteristics of shredded rubber tire sand mixtures." Canadian Geotechnical Journal 40, no. 2 (2003): 254-264.

[5] Ghazavi, Mahmoud, and MasoudAmelSakhi. "Influence of optimized tire shreds on shear strength parameters of sand." International Journal of Geomechanics 5, no.1 (2005): 58- 65.

[6] Rao, G. Venkatappa, and R. K. Dutta. "Compressibility and strength behaviour of sand-tyre chip mixtures." Geotechnical \& Geological Engineering 24, no. 3 (2006): 711-724.

[7] Ghazavi, Mahmoud. "Shear strength characteristics of sand-mixed with granular rubber."Geotechnical \& Geological Engineering 22, no. 3 (2004): 401-416.

[8] Cetin, Hasan, Mustafa Fener, and Osman Gunaydin. "Geotechnical properties of tire- cohesive clayey soil mixtures as a fill material." Engineering Geology 88, no. 1 (2006): 110-120.

[9] Yoon, Sungmin, Monica Prezzi, Nayyar Zia Siddiki, and Bumjoo Kim. "Construction of a test embankment using a sand-tire shred mixture as fill material." Waste Management 26, no. 9 (2006): 1033-1044.

[10] Bernal, A., R. Salgado, R. H. Swan, and C. W. Lovell. "Interaction between tire shreds, rubber-sand and geosynthetics." Geosynthetics International 4, no. 6 (1997): 623-643

[11] Tweedie, Jeffrey, Dana Humphrey, and Thomas Sandford. "Full-scale field trials of tire shreds as lightweight retaining wall backfill under at-rest conditions." Transportation Research Record: Journal of the Transportation Research Board 1619 (1998): 64-71. 